\title{
Improving the understanding of the risk from groundwater flooding in the UK
}

\author{
D.M.J. Macdonald, J.P. Bloomfield, A.G. Hughes, A.M. MacDonald, B. Adams \& \\ A.A. McKenzie \\ British Geological Survey, Maclean Building, Wallingford, Oxfordshire OX10 8BB, UK
}

\begin{abstract}
Groundwater flooding has been shown to be a significant component of the risk from flooding in the UK. Its inclusion within the EU Floods Directive highlights the need to understand more about the processes that control groundwater flooding and to define the associated risk. In this paper the main groundwater flooding scenarios are described and the challenges in estimating return periods and mapping risk set out. In addition, ongoing and recently completed work by the British Geological Survey which aims to improve the understanding of risk from groundwater flooding in the UK is presented.
\end{abstract}

\section{INTRODUCTION}

Groundwater flooding can cause significant social and economic disruption and is a threat in many areas of north-west Europe. For example, in the first assessment of its kind in England and Wales, Jacobs (2004) estimated that 380,000 properties are located on the most vulnerable formations, the exposed Chalk of southern England. The scale of the problem has been recognised by the Department for the Environment, Food and Rural Affairs (Defra) which, through the Environment Agency of England and Wales (EA), is looking at the establishment of a national database of flooding from all sources, including groundwater, and the extension of its flood risk maps and warning service to cover groundwater.

The characteristic feature of groundwater flooding events is the relatively long duration compared with fluvial flooding. Groundwater flooding is defined here as the emergence of groundwater at the ground surface away from perennial river channels or the rising of groundwater into man-made ground, under conditions where the 'normal' ranges of groundwater level and groundwater flow are exceeded. The impact of groundwater flooding can occur before water levels reach the ground surface where there is inundation of building basements and buried services or other assets below ground level. Groundwater levels that rise above ground have the potential to reach low-lying areas protected from fluvial flooding. Exceptionally large flows from perennial springs or large flows from intermittent or dormant springs, which also come under the above definition of groundwater flooding, can cause both localised flooding in the vicinity of the springs and down gradient where surface water drainage channels may not be adequate.

\section{GROUNDWATER FLOODING SCENARIOS}

There are three scenarios described here for groundwater flooding. Firstly, long-lasting, often regionally extensive, groundwater flooding can be caused by the water table in an unconfined aquifer rising above the land surface as a response to extreme rainfall (Fig. 1). This is often referred to as clearwater flooding. It is this form of flooding that has caused significant damage to properties on the Chalk outcrop of southern England in recent years. Flooding occurs when antecedent conditions of high groundwater levels and high unsaturated zone moisture content combine with intense rainfall. In the Chalk this can cause groundwater levels to fluctuate over several tens of metres. For example, in the winter of 2000/1 groundwater flooding was associated with unusually high levels of rainfall: for an eight month period starting in September 2000, rainfall in south east England was $183 \%$ of the long-term average, equivalent to a greater than 100 year return period. Groundwater levels were already high as there had been several years' above average recharge. Significant flows occurred in dry valleys in localities remote from floodplains. River flow reflected the high rainfall as well as the contribution from groundwater discharge. Flows at most river gauging stations greatly exceeded the long-term averages for ex- 
tended periods. In some catchments sustained groundwater flooding occurred for several months.
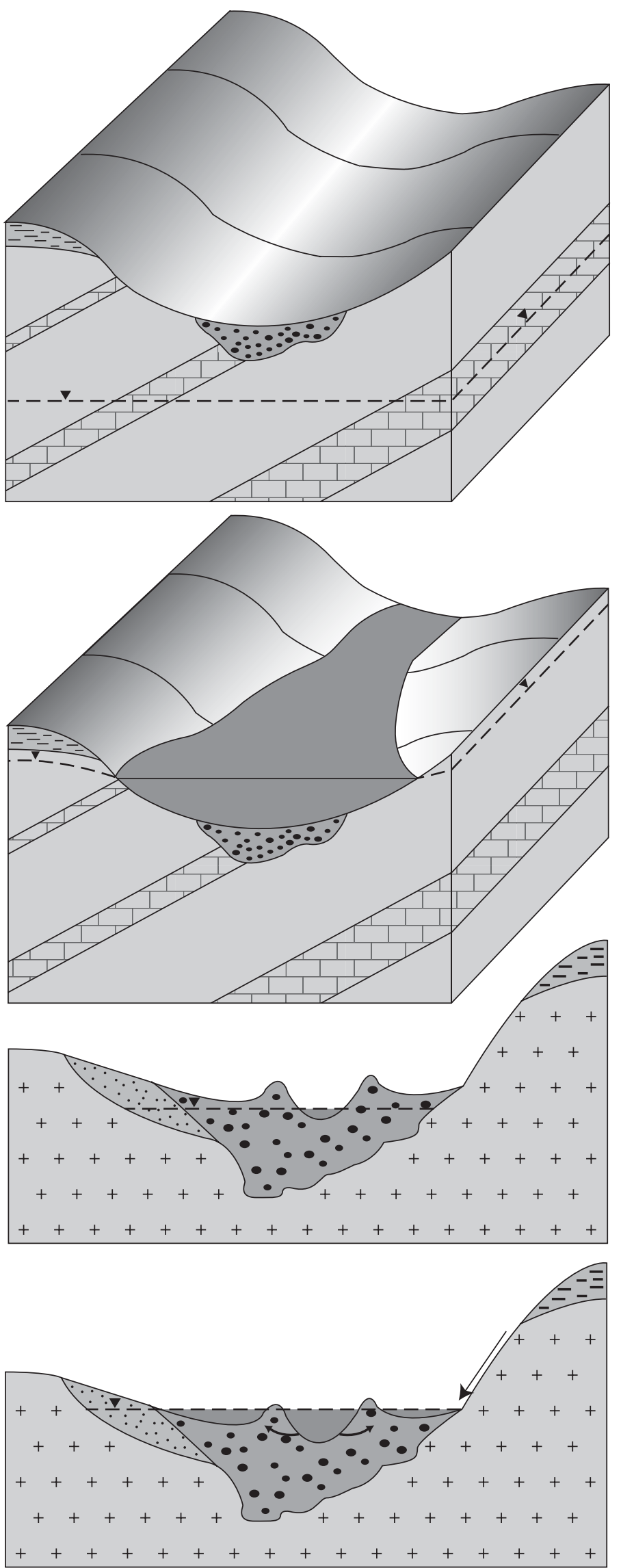

Figure 1. Schematics illustrating groundwater flooding in two hydrogeological settings: an unconfined, consolidated aquifer (top); and shallow, unconsolidated sediments underlain by a poorly permeable aquifer (bottom). BGS (C) NERC.
A second scenario for flooding is associated with shallow unconsolidated sedimentary aquifers which overly non-aquifers. These aquifers are susceptible as the storage capacity is often limited, direct rainfall recharge can be relatively high and the sediments may be very permeable, creating a good hydraulic connection with adjacent river networks. Groundwater levels are often close to the ground surface during much of the year (see Section 4.2.2). Intense rainfall can cause a rapid response in groundwater levels; rising river levels, as the upstream catchment responds to the rainfall, can create increased heads that drive water into the aquifer (see Section 4.2.1). Natural levees and man-made structures can allow river levels to rise without breaking their banks; groundwater flooding will occur in lowlying areas beyond the banks, preceding any fluvial flooding and lengthening the overall period of flooding. However, flooding in these systems can be relatively short-lived compared with Chalk flooding as rivers, returning to pre-flooding levels, quickly drain the highly permeable aquifer. These hydrogeological settings often coincide with urban areas and it is clear that the role of groundwater in flooding needs to be addressed as the traditional engineered methods of flood protection may be circumvented by flow through the subsurface. The difficulty is that it can be hard to distinguish this type of groundwater flooding from fluvial or pluvial floods.

The third scenario for groundwater flooding occurs where there has been a reduction in abstraction from large aquifers underlying major urban centres due to a reduction in industrial activities. This has allowed depressed groundwater levels to recover causing the risk of flooding to subsurface infrastructure, such as tunnels and the basements of buildings, as well as changes in geotechnical and geochemical properties that could result in settlement and corrosion of deeply founded structures. This groundwater rebound has occurred in some of the UK's major conurbations including London, Birmingham, Nottingham and Liverpool. In London in the late 1990s a group of stakeholders, including Thames Water, the EA and London Underground, developed a strategy to address this risk by increasing groundwater abstraction from the confined Chalk aquifer underlying central London by around 50 million litres per day, using this water for public and private supply (Jones, 2007). This has resulted in the stabilisation of groundwater levels.

\section{ASSESSING THE RISK FROM GROUNDWATER FLOODING}

In England and Wales, the EA does not have explicit responsibilities or powers relating to ground- 
water flooding. However, it is expanding its regional activities in this area and has established monitoring and warning arrangements in regions most at risk of flooding from Chalk aquifers (see below). This was a recommendation from the independent review (Pitt, 2007) of the impact of the devastating floods that affected the UK in the summer of 2007 (Marsh \& Hannaford, 2008). The review recommended that more frequent and systematic monitoring of groundwater levels at times of high risk should be undertaken by the EA.

The EU Floods Directive (2007/60/EC) which came into force in November 2007 includes provisions for groundwater flooding. The Directive states that 'Member States may decide that, for areas where flooding is from groundwater sources, the preparation of flood hazard maps shall be limited to...floods with a low probability, or extreme event scenarios'. The definition of 'floods with a medium probability' as having a likely return period of 100 years or more helps to define what is meant by low probability. The implication is that groundwater flooding is thought unlikely to have significant impacts at return periods of less than 100 years. Evidence from the UK would contradict this.

There are, however, significant difficulties with assigning probabilities to groundwater floods; these are summarised in Jacobs (2006). Fundamental to assessing flood probabilities is evidence of the location and timing of past flooding. In relation to groundwater flooding there are particular problems with identifying where groundwater was the source of flood waters. The EA have identified the collation of historical data and the development of procedures of capturing data on future groundwater floods as the first major requirement in their strategy to map the risk of groundwater flooding.

In addition, difficulties arise in assessing the return periods of groundwater floods. The commonly used methods for fluvial flood analysis rely on the use of time series data that are not serially dependent (Najib et al. 2007) but the incidence of groundwater flooding, particularly in the Chalk aquifer, can be highly dependent on antecedent conditions (there is some regional variation in the degree of dependence, see Section 4.1.1). In addition, there are a limited number of sufficiently long groundwater level time series available. Also, those available can have intervals between measurements that are highly variable and which may mean periods of high groundwater levels associated with flooding are missed. The heterogeneity of aquifer systems and paucity of measurement points also causes difficulty in obtaining representative levels.

As a result of these difficulties, few approaches have been developed for groundwater flood risk mapping in the UK. JBA (2006) have used the annual maximum series approach based on 3-month average groundwater levels in combination with a digital terrain model (DTM) to produce flood risk maps for a few pilot sites. Jacobs (2004) produced maps of 'ground emergence' for Defra which cover the consolidated aquifers of England (Morris et al. 2007). Groundwater level contours and a DTM were used to calculate depth to groundwater which was then translated to match areas of zero depth with known locations of groundwater flooding in the winter of 2000/1. BGS has also produced national groundwater flood susceptibility maps although these do not include probability or impact elements (see Section 4.3).

Early warning systems for groundwater flooding have been produced. The EA have set-up local flood watches based on groundwater levels in indicator boreholes from which levels have previously been correlated with occurrences of groundwater flooding. Warnings are sent out when trigger levels are reached. Bradford \& Croker (2007) have proposed the correlation of groundwater level with streamflow in Chalk catchments as a means to develop fluvial groundwater flood warnings. BGS has applied a multi-linear regression model based on groundwater levels, rainfall probabilities and unsaturated zone matric potentials (see Section 4.1.1).

This is a developing area of science with a clear need as risk mapping is necessary for planning policy. However, there is much to be done to match the level of sophistication of fluvial flood mapping.

\section{IMPROVING THE UNDERSTANDING OF GROUNDWATER FLOODING}

The British Geological Survey (BGS) is involved in a number of ongoing and recently completed projects that aim to improve the understanding of groundwater flooding processes and the associated risks. This section outlines results of these groundwater flooding projects.

\subsection{Groundwater flooding from Chalk aquifers}

\subsubsection{FLOOD 1}

The unsaturated zone plays a fundamental role in the generation of Chalk groundwater floods, however, previously it has not been part of any flood monitoring system. FLOOD 1, which finished in June 2008, was a three-year project within the EU INTERREG 111A Anglo French programme which aimed to address this issue (Adams et al., in prep.). Project partners were BGS, the University of Brighton and the French Geological Survey (BRGM). Using groundwater flooding case studies in Brighton and the Pang River catchment in Berkshire, the aims of the UK arm of the project were to: 
1 understand the hydraulic behaviour of water flow in the unsaturated zone which leads to triggering of groundwater flood events; and

2 produce appropriate methodologies and tools for forecasting groundwater flood events capable of operating within a much longer timescale than was previously possible (i.e. days and weeks rather than hours).

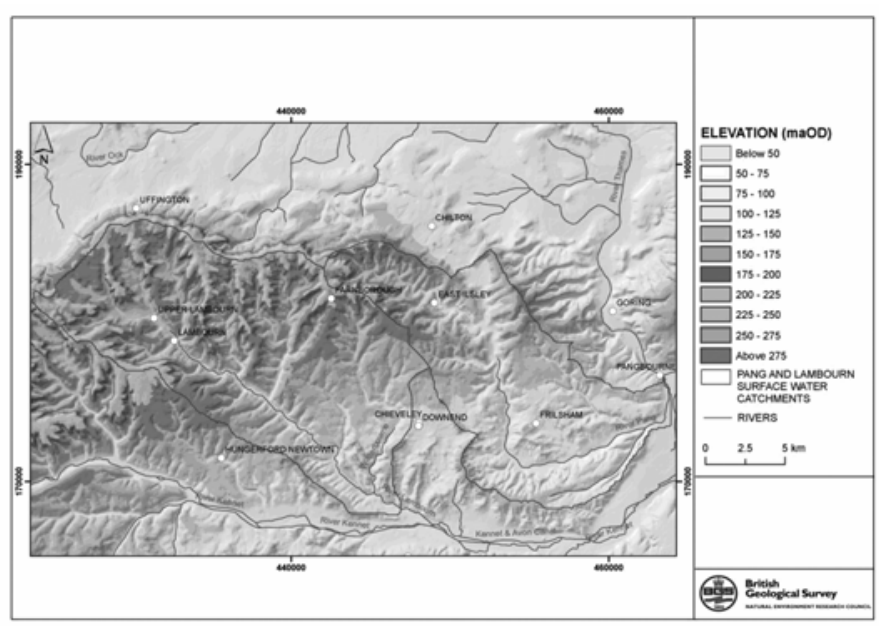

Figure 2. Location map showing the Pang and Lambourn catchments. BGS (C) NERC. OS Topography (C) Crown Copyright. All rights reserved.

Previous studies identified that the majority of flow in the unsaturated zone of the Chalk is by intergranular flow (Smith et al. 1970) which led to the development of the concept of 'piston flow' whereby the rapid response of the water table is due to piston-displacement of water within the unsaturated zone (Price et al. 1993). The Chalk matric pore spaces do not drain to any significant degree due to the narrow throats of individual pores, however, water held on the surfaces of the fractures in the Chalk by suction becomes mobile when the potential in the matrix falls below a threshold (Price et al. 2000). Large rainfall events can cause the threshold matric potential to be reached very quickly causing a rapid release of water. The associated rise in the water table can lead to groundwater flooding. Through downhole instrumentation and survey, FLOOD 1 has been the first study to collect direct evidence of the release of water held on the surfaces of the fissures in the Chalk.

In addition to detailed studies of unsaturated zone processes in the Chalk, a statistical approach to predictive modelling of high groundwater levels has been developed through the project. This is based on the observation that groundwater flooding can be associated with high antecedent groundwater levels and exceptionally high rainfall. The importance of antecedent conditions appears to vary in different areas with autocorrelation in Chalk groundwater levels ranging from greater than a year to shorter periods. This is illustrated by a comparison of groundwater flooding in Brighton, where flooding lasts for a few weeks, to the Hallue area of France which, with similar rainfall events, had flooding which lasted for several months. It is thought that the 'flashy' response of some catchments is because the nature of the Chalk means higher matric potentials are maintained at depth.

A multiple linear regression method was developed to predict maximum annual groundwater levels. The model describes the maximum annual groundwater levels adequately with the exception of winter 2000/1, where the model slightly overpredicts the groundwater levels. It is thought that this can be explained, at least in part, by the observation that the true maxima during the winter of 2000/1 was likely to have been higher than the observed maxima. The regression model can be used in a Monte Carlo simulation to predict a range of possible maximum groundwater levels that may be expected, given an observed annual groundwater level minima. As this model can be run as soon as the minimum groundwater level is known, the model provides a prediction of the range of maximum groundwater levels months in advance of the maxima being reached, typically six to nine months in advance.

Based on the research undertaken on the FLOOD1 project and the statistical methods developed a generic, nested early warning system (EWS) was devised. This involves consideration of antecedent groundwater levels, rainfall probabilities and monitoring of the wetting up of the unsaturated zone The EWS is now undergoing testing and will require the identification of trigger points at which progressive flood warnings should be given out.

\subsubsection{Modelling groundwater flood risk in the Chalk aquifer}

During the winter of 2000/1, elevated groundwater levels caused widespread flooding in the Pang and Lambourn catchments in southern England (Fig. 2). These catchments, underlain by Chalk, experienced groundwater flooding in normally dry valleys. The flooding caused closure of roads, inundation of basements and the flooding of recently built properties on lower lying land. The flooding was prolonged and lasted well into the spring of 2001. Aerial photography and walkover surveys recorded the extent of the problem and showed the flooding to be predominantly a reactivation of previously dry valleys. Further flooding occurred in the winter of 2002/3 and in the summer 2007. The former flood events coincided with data collection for the Natural Environment Research Council (NERC) LOwland CAtchment Research (LOCAR) thematic programme. Data collected both during the LOCAR programme and immediately after by BGS will be extremely useful in examining these further flood events. 
A project under the NERC Flood Risk from Extreme Events (FREE) thematic programme is being undertaken (2007-2010) to understand and simulate groundwater flooding in the Pang and Lambourn catchments. The project, entitled "Modelling groundwater flood risk in the Chalk aquifer from future extreme rainfall events" (NE/E002307/1), consists of a consortium of scientists from Imperial College, the Centre for Ecology and Hydrology and BGS. The project aims to develop an integrated modelling system based on existing codes. The system consists of soil (JULES), unsaturated zone and saturated zone (ZOOMQ3D) models. Included in the suite of models is a regional climate model which will allow the examination of how the frequency of groundwater flooding will change under conditions of climate change. Once groundwater flooding can be simulated in the Pang and Lambourn catchments using complex models, then a simplified approach will be developed for these catchments and applied to the Chalk outcrop in the UK.

To-date a hydrogeological understand has been developed of groundwater flooding in the Pang and Lambourn catchments events in winter 2000/1. Data for these catchments, including groundwater level and river flow hydrographs have been assembled and examined. Groundwater level contour plots and cross-sections have also been produced. These have been combined with topographical information and maps of flooding extent. To aid the hydrogeological understanding, a groundwater flow model has been developed using an existing ZOOMQ3D model (Jackson et al. 2006) developed for the LOCAR project. The model has been run using monthly stress periods from 1971 to 2003 and daily stress periods during the water year (1 October 2000 to 30 September 2001) when groundwater flooding occurred. The model output has been compared against groundwater hydrographs, river baseflows and the mapped flood extent.

Examining the observed groundwater and baseflow hydrographs has shown that there is a characteristic hydrograph that occurs in the Pang and Lambourn catchments. This hydrograph exhibits a rapid rise during December 2000, followed by a plateau of high groundwater or baseflow. This plateau lasted well into the spring, until June 2001. Further, during the period that groundwater levels and baseflow was high, three additional peaks are observed due to extra rainfall recharge during the winter period. The groundwater modelling shows that the detail of the groundwater hydrographs can be reproduced reasonably well as can the reactivation of the dry valleys. The modeling has also provided further insights into the timing of groundwater arriving at the water table; this is modelled as lagging by one month during typical recharge periods but much shorter periods subsequent to extreme events such as in the winter of 2000/1.
The next step is to improve the simulation of the onset and persistence of flooding in the winter of 2000/1 prior to carrying out an identical exercise for floods in winter 2002/3 using the more detailed LOCAR data.

\subsection{Groundwater flooding in unconsolidated sediments}

\subsubsection{Groundwater and flooding in Oxford}

Oxford is situated within a relatively narrow valley of the upper River Thames (Fig. 3). Although most of the city is located on older river terraces above the current floodplain, from the late $19^{\text {th }}$ Century pressure for housing near to the city centre resulted in significant urban development on the floodplain; it is estimated that currently 3600 primarily residential but also commercial properties are located within the $1 \%$ flood event envelope. The city suffers from recurrent floods, most recently in December 2000, January 2003 and July 2007. The July 2007 event was the largest flood since 1947, having an approximate return period of 1 in 20 years and inundating around 200 properties (N. Blazey, Black \& Veatch, pers. comm.). Flooding occurred due to both rising groundwater levels and overbanking of the Thames and its tributaries.

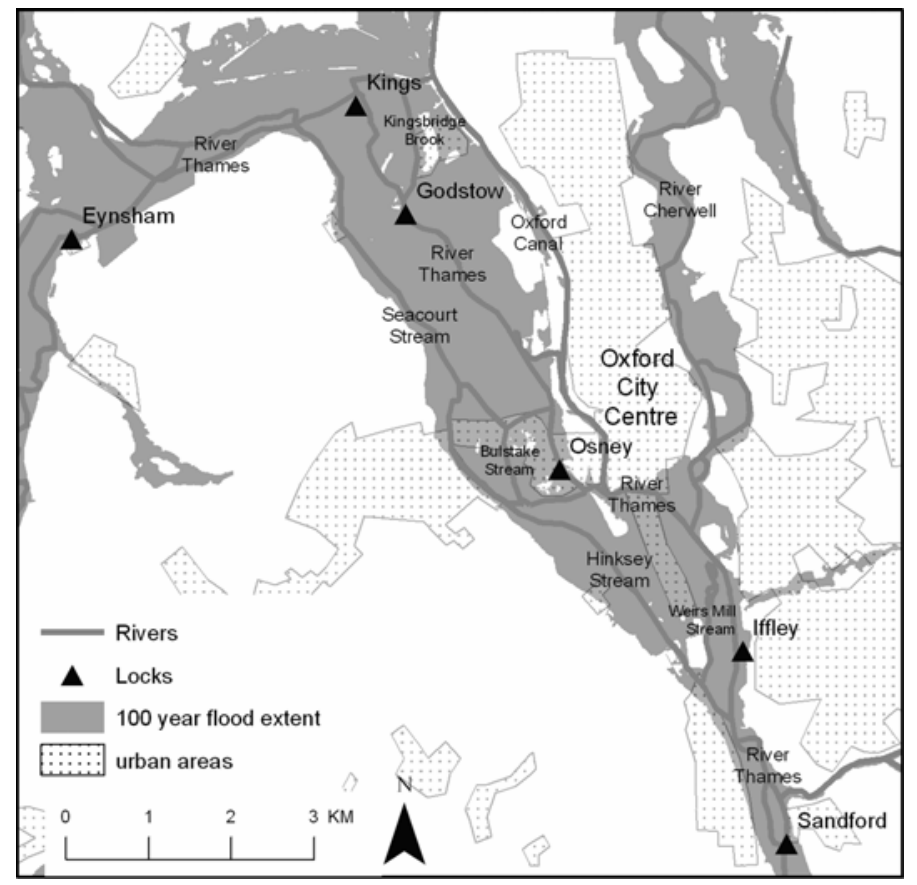

Figure 3. Oxford area showing the 100 year flood extent, the river network and the urban areas. OS rivers and urban area (C) Crown Copyright. All rights reserved.

BGS is undertaking a project examining the role of groundwater in flooding on the Oxford floodplain (Macdonald et al. 2007). The project is in collaboration with the EA and is linked with its Oxford Flood Risk Management Strategy. The understanding 
gained from the joint project will help the EA examine their risk management options.

The high ground that surrounds the Oxford valley is formed by sandstones, limestones and clays of Upper Jurassic and Lower Cretaceous age, as well as older terrace gravels of the River Thames. The current floodplain deposits are made up of sands and gravels, generally forming a relatively uniform sheet of typically 2 to $4 \mathrm{~m}$ thickness (although there are thicker areas of up to $8 \mathrm{~m}$ ), largely occluded by a cover of silty, clayey alluvium. The gravels are underlain by the Upper Jurassic Oxford Clay (Newell, 2007).

Saturated hydraulic conductivities have been determined from pumping and packer tests and independently estimated from grain size distributions. Results suggest a range of hydraulic conductivity between 100 and $1000 \mathrm{md}^{-1}$ for the gravel aquifer (Dixon, 2004). A large number of groundwater and surface water monitoring points existed prior to the current project, primarily focused on assessing any detrimental impact on a Special Area of Conservation (SAC) in the north of the valley due to dewatering for gravel extraction and drought permits for river abstraction upstream. As part of the project this monitoring network was expanded to the south where the majority of the flood-prone urban areas are located.

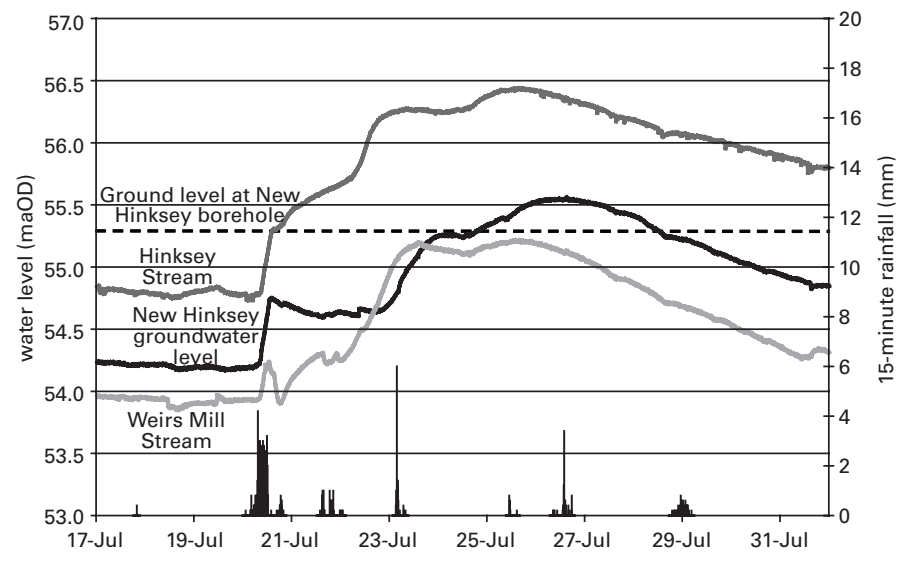

Figure 4. Groundwater and river hydrographs from Oxford from the period around the July 2007 flood. BGS (C) NERC.

As it passes through Oxford, the River Thames anastomises before forming a single channel again as it reaches the southern end of the valley. The principle channel other than that of the Thames itself is the Seacourt Stream, which changes its name in the southern part of the valley to the Hinksey Stream. Inflow to the Seacourt Stream from the Thames is controlled by a fixed head weir.

Examination of surface water and groundwater hydrographs has shown the strong hydraulic connection between the rivers and streams in the valley and the underlying gravel aquifer. River management structures have a significant bearing on groundwater flow patterns within the aquifer. Relatively high head levels upstream of the six locks on the River Thames within the study area have been shown to create zones of recharge to the gravel aquifer, with the lock bypass channels forming zones of groundwater discharge. Groundwater responses to rainfall are marked, with rises in levels seen within hours of rainfall events.

An assessment of the role of groundwater in flooding can be most readily made by examining the nature of flooding in Oxford in July 2007. On $19^{\text {th }}$ and $20^{\text {th }}$ July an extreme rainfall event occurred in Central England. During this period the rainfall in the centre of Oxford totalled $60.6 \mathrm{~mm}$, however, in the head waters of the Thames and its tributaries the rainfall event was measured at over $110 \mathrm{~mm}$ for a 24-hour period (Marsh \& Hannaford, 2008). There was an almost immediate response in river and groundwater levels in Oxford occurring within 4-8 hours from the start of the event (Fig. 4). In the 17 boreholes with automatic water level recorders, which are well-distributed across the study area, an average increase in groundwater level of $0.59 \mathrm{~m}$ was seen, ranging from $0.28 \mathrm{~m}$ to $1.23 \mathrm{~m}$. Groundwater flooding did not occur at any of these sites during this initial period although in all cases groundwater levels rose into the alluvium. There followed a period of recession of up to a few days following this initial peak in groundwater levels. Due to the large amount of rainfall within the headwaters of the Thames and its tributaries there were two peaks in flows and associated river levels in Oxford (Fig. 4). The first peak arrived in Oxford valley just over two days after the start of the rainfall event in Oxford; the second peak arrived after five days. The rises in river levels were markedly greater in the Seacourt/Hinksey Stream than in the Thames, maximum measured levels being $2.02 \mathrm{~m}$ and $1.31 \mathrm{~m}$ respectively.

Urban development and the road and rail infrastructure have changed floodplain topography significantly in Oxford. During flooding periods flows down the catchment are constrained by these developments which create a network of flood cells. For example, the Botley Road and associated urban area, which runs west to east across the floodplain perpendicular to flood water flows, causes water to bank upstream to its northern side. The New Hinksey residential area which runs north to south in the south of Oxford separates the Hinksey Stream side of the valley from the River Thames side. The flow down the Hinksey Stream side is constrained to the south by the road network, river management structures and by a series of land dumps. The combination creates a cell to the west of New Hinksey which in July 2007 had flood water levels significantly higher than in the Thames side. The heads created by these cells can be seen to cause a rapid and significant response in groundwater levels down- 
gradient due to the strong hydraulic connection between flood waters and the gravel aquifer (Fig. 4).

In the majority of groundwater monitoring sites referred to above, groundwater levels were artesian (above ground level) during the latter period of the flood event. This rise in groundwater was driven by the flood waters, particularly where the movement of these flood waters was constrained by urban development allowing a greater driving head for recharge to the gravel aquifer to be established. The recharge from the flood waters came on top of high groundwater levels resulting from direct recharge during the rainfall event itself. In most locations groundwater flooding was masked by fluvial flooding, however, in some locations where high surrounding urban areas protected ground from fluvial flooding, groundwater was the only source of flooding. Basements created by the building up of houses from the natural floodplain level, which were subsequently converted into living areas, are particularly vulnerable to this form of flooding.

These insights have implications for the design of flood mitigation measures and indicate that by addressing fluvial flooding by ensuring faster movement of flood waters through the Oxford floodplain the risk from groundwater flooding may be significantly reduced.

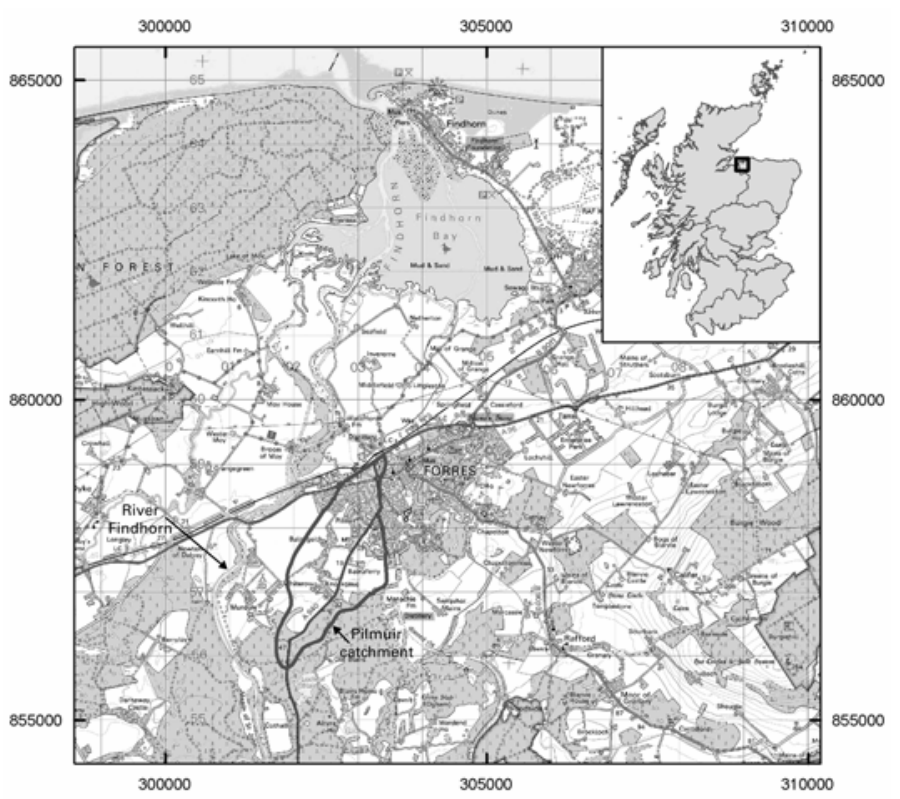

Figure 5. Location map for the town of Forres, Morayshire showing the Pilmuir catchment. OS (C) Crown Copyright. All rights reserved.

\subsubsection{Flooding in the Forres area of Morayshire}

To help protect the flood-prone town of Forres in Morayshire, north-east Scotland, a flood alleviation scheme is proposed for west Forres and the Pilmuir area (Fig. 5). This scheme involves a series of embankments and river channel engineering to stop the westward movement of flood water from the River Findhorn through Forres, and a series of drains to remove storm water from the Pilmuir catchment. A critical issue in the operation and effectiveness of the flood alleviation scheme is the role of groundwater.

Work was undertaken by BGS to assess the groundwater aspects of flooding and implications for the efficacy of the proposed alleviation scheme as well as the impacts of further urban development, focussing on the Pilmuir area, (MacDonald et al. 2008). The project was funded by Moray Flood Alleviation. The Pilmuir area is generally low lying and subject to considerable new development for houses. There are no streams or rivers within the catchment and rainfall discharges primarily through groundwater flow to a series of storm water drains at its lower end. The proposed scheme would create a drain which takes water out of the middle of the Pilmuir catchment and discharges west to the River Findhorn and would also involve the development of a series of embankments to stop eastward migration of floodwaters from the River Findhorn.

Hydrogeological investigations undertaken by BGS indicate that there is a dual aquifer system in the Pilmuir catchment, with a shallow superficial sands and gravel aquifer that is generally highly permeable, underlain by a deeper, less-permeable bedrock aquifer. Groundwater flow, mostly within the top $8 \mathrm{~m}$, is generally from south to north, following the topographic gradient. Groundwater discharges constantly through the existing storm drain system in Pilmuir. Groundwater levels are shallow and approach ground surface in parts. The River Findhorn is well-connected to the aquifer system.

From the groundwater investigations it is possible to infer mechanisms for flooding in the Pilmuir area. Very shallow groundwater gives rise to marshy areas, some peat development and willow growth in the Pilmuir area. The water-logged soils also reduce the ability of rain to infiltrate, leading to large areas of ponded water for parts of the year. The increased urbanisation in the upper part of the catchment is likely to have increased runoff, and the use of soakaways will have raised groundwater levels in the lower part of the catchments. Groundwater also plays a role in the larger flood events. Generally, the high infiltration capacity of the soil in the upper parts of the catchment means that runoff is limited, and the flood extent is reduced. However, this recharge can have a longer-term impact on groundwater levels, increasing the risk of ponding at other times of the year. The constant groundwater discharge through the existing storm water drain also reduces the capacity of the drain to discharge runoff during flood events.

The following general recommendations were made for development in the catchment. Since the most likely cause of annual flooding in the lower lying areas of the catchment is elevated groundwater levels, disposing of excess water to groundwater (either through soakaways or seepage of flood water) 
may increase the likelihood and scale of flooding and therefore disposal of excess water to groundwater would have to be minimised. Increased urbanisation in the catchment will lead to greater amounts of runoff which will have to be disposed of safely and sustainably and preferably not to groundwater. Therefore, it was recommended that before agreeing any new building in the area, the effect of development on flooding and groundwater is thoroughly examined. The groundwater discharge through the existing storm water drains reduces their capacity to accommodate runoff in the lower part of the catchment and therefore recommendations were made about the design of proposed drainage to ensure this takes most of the runoff and intercepts groundwater.

Heavy rainfall events raise groundwater-levels across the entire area and considerably increase the extent of shallow groundwater levels and potential groundwater flooding. Input to the aquifer system from the River Findhorn during periods of flooding also raises groundwater levels. An embankment to store flood waters upstream of the urban area is proposed to reduce peak flood levels in the River Findhorn. There was concern that the water held within this embankment could seep into the shallow groundwater system and significantly increase the potential for groundwater flooding. Investigations were undertaken to allow conditions around the area of proposed embankment to be modeled to assess the effect of various flooding scenarios on general groundwater conditions. Results showed, for example, that the effect of impounding flood waters behind embankments for one day allows flood water to enter the groundwater system and raise groundwater levels beneath the impounded area. However, the overall groundwater level rise would be much less than if the embankment was not in place and flood waters were allowed to spread over a larger area. The area of significant groundwater level rise is largely constrained to near the river and the additional groundwater flooding in the Pilmuir area from the impoundment was not predicted to be significant. The detailed groundwater investigations and grou-ndwater modeling allowed the various scheme de-signs to be tested and improved.

\subsection{Groundwater flood susceptibility mapping}

BGS has produced the first national map of groundwater flooding susceptibility for Great Britain (Bloomfield et al. 2007). Based primarily on geological criteria, the map identifies areas where groundwater is close to the surface and where geological conditions suggest that these areas are susceptible to groundwater flooding (the map addresses geological susceptibility to groundwater flooding rather than the risk from groundwater flooding events which requires information on flood return periods as well as the impact on property and infrastruc- ture). The first step in the methodology for creating the maps was to develop simple but geologically and hydrogeologically realistic conceptual models of groundwater flooding processes. Two conceptual models are included within the map, for flooding in shallow, permeable, unconsolidated sediments (referred to in the mapping methodology as permeable superficial deposits - PSD) and clearwater flooding, as described in Section 2 (there are plans to include a third model for anomalous spring flow flooding). The map was produced using a GIS and a 'rulebased' approach. The first step was to mask out areas not prone to groundwater flooding. This used a national permeability dataset derived based on 1:50,000 scale mapping of the geology of Great Britain undertaken by BGS. In this dataset, rock type is attributed with a permeability classification based on expert judgement (Lewis et al. 2006). The following permeability attributes are used:

- predominant flow mechanism (fracture, intergranular or mixed flow);

- maximum permeability (very high, high moderate, low and very low);

- minimum permeability (very high, high, moderate, low and very low).
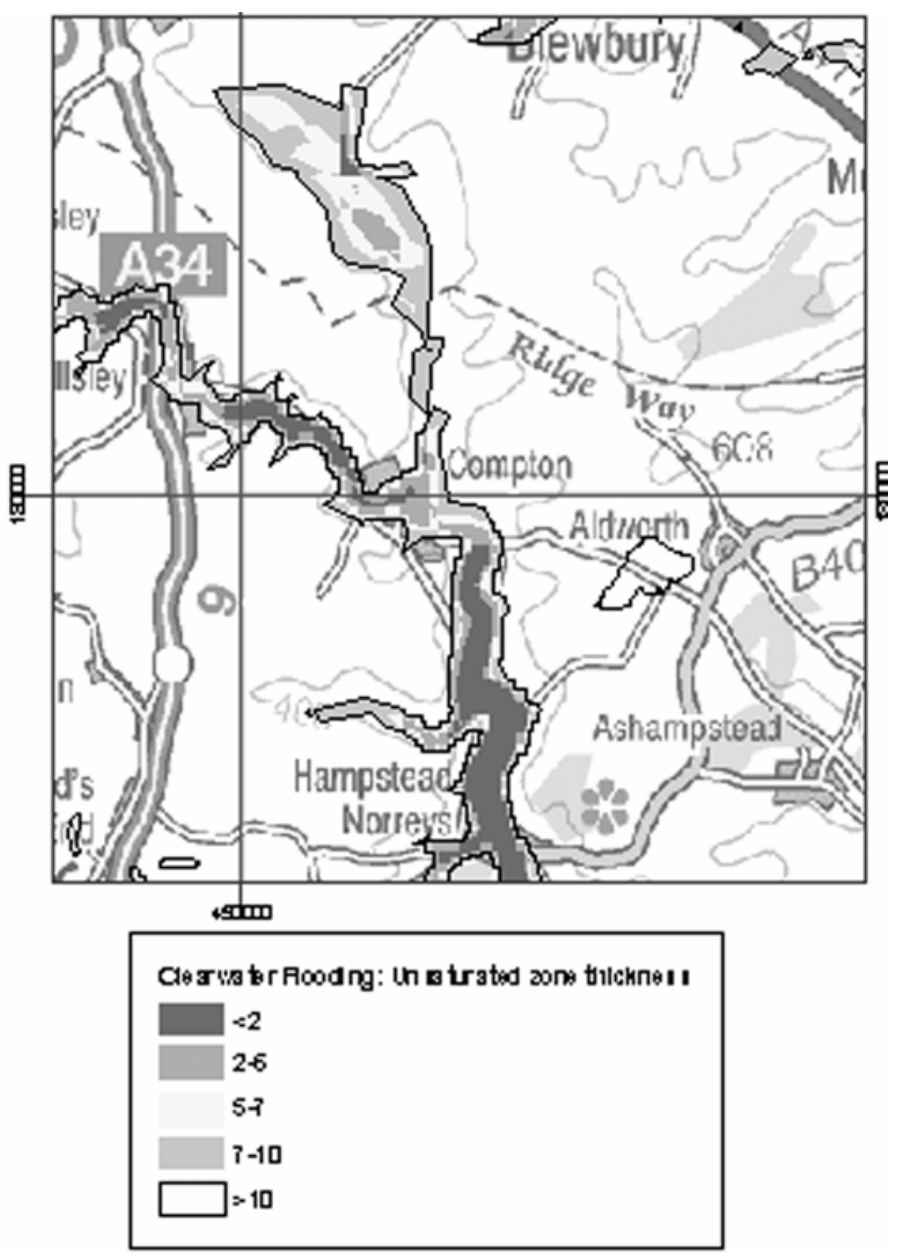

Figure 6. Excerpt from the BGS Groundwater Flood Susceptibility Map. BGS (C) NERC. OS Topography (C) Crown Copyright. All rights reserved. 
The PSD flooding mask includes all superficial deposits with maximum permeability values of very high and high, with underlying bedrock with minimum permeability values of low and very low. The clearwater flooding mask includes all bedrock aquifers with maxiumum permeability values of very high and high, except those overlain by superficial deposits with maxiumum permeability values of low and very low. All other areas are assumed not to be susceptible to groundwater flooding.

The PSD rule-based model uses a derived river network. As the conceptual model assumes groundwater in the permeable deposits are in hydraulic connection with rivers, those polygons at a significant distance from the river network are excluded. Depth to groundwater is calculated for the remaining polygons based on a groundwater level surface. As there are insufficient observed measurements from which to contour this surface it was modelled by assuming good hydraulic connection between rivers and groundwater and by assigning groundwater levels by interpolating levels between neighbouring rivers and river and coastline. The river base level was calculated from a 50-metre digital terrain model grid. Depth to groundwater was calculated by subtracting the estimated groundwater level from the ground surface height taken from a DTM. There are limitations in this approach, for example, some rivers have large seasonal variations in stage, however, the surface has been tested against the limited number of direct observations that are available in digital form and a fair correlation is found between observed and modelled.

The first step in the clearwater flooding model was the creation of a 'minimum' groundwater level surface, as many of the larger groundwater level datasets and contours are for conditions of average or low groundwater level surface. This minimum surface was then modified to represent a high groundwater level stand. Three types of groundwater levels were used:

- groundwater levels taken from contours on published BGS hydrogeological maps and from other digitized contours;

- point groundwater level data held by BGS; and

- where there were no other data, groundwater levels inferred from adjusted river base levels.

The groundwater levels based on the river base level were adjusted recognizing there is some degree of 'mounding' of the piezometric surface under the interfluves. This uses a relationship derived from observed data, taking into account the aquifer permeability classification.

The overall groundwater surface derived represents a low groundwater level but, as discussed in Section 3, clearwater flooding tends to occur when antecedent conditions are high and after periods of exceptionally high recharge. The groundwater surface therefore needed to be adjusted to give a 'maximum' level. The degree of adjustment was identified using data available on groundwater level fluctuation, in combination with models relating to distance from river.

Finally, the two flood masks were combined and the degree of susceptibility to groundwater flooding categorized based on the depth to groundwater. The most susceptible areas are those were the depth to groundwater is less than two metres (Fig. 6). Susceptibility zoning has been validated qualitatively based on limited information related to recent groundwater flooding events, primarily on the Chalk.

It is envisaged that the groundwater flooding susceptibility data could be used for area, regional, subnational or national planning purposes where the groundwater flooding information will be used, along with a range of other relevant information, to inform land-use planning decisions. It might be used in conjunction with a large number of other factors, including records of previous incidence of groundwater flooding, rainfall, property type and land drainage information, to establish relative, but not absolute, risk of groundwater flooding at scales greater than a few hundred metres.

\section{CONCLUSIONS}

The need to quantify the risk from groundwater flooding has been shown here. The difficulties in estimating the probabilities of groundwater flooding occurring and in mapping risk have been presented. However, it is clear that the requirement has been recognized and that the research community is beginning to address the issue. The British Geological Survey plans to continue to play a significant role in improving the understanding of the role of groundwater flooding in the UK and the rest of Europe.

\section{REFERENCES}

Adams, B., Williams, A.T., Bloomfield, J.P., Jackson, C.R., Gallagher, A.J. \& Rutter, H.K. in preparation. FLOOD 1: British Geological Survey Final Report.

Bloomfield, J.P., McKenzie A.A., Rutter H.K. \& Hulbert A. 2007. Methodology for mapping geological controls on susceptibility to groundwater flooding. British Geological Survey Internal Report, IR/07/072.

Bradford, R.B \& Croker, K.M. 2007. Application of head-flow responses to groundwater floods in Chalk catchments. Quarterly Journal of Engineering Geology and Hydrogeology 40: 67-74.

Dixon, A. 2004. The hydrology of Oxford Meadows cSAC. Groundwater Monitoring and Drilling Ltd Report.

Jackson, C.R., Hughes, A.G. \& Mansour, M.M. 2006. Numerical modelling of groundwater flow to Gatehampton. British Geological Survey Commissioned Report CR/06/205C.

Jacobs 2004. Strategy for flood and coastal erosion risk management: groundwater flooding scoping study (LDS 23) Final Report. 
Jacobs 2006. Groundwater flooding records collation, monitoring and risk assessment (reference HA5): extended report (Chalk aquifers).

JBA 2006. Flooding from other sources (HA4a): Draft Final Report.

Jones, M. 2007. Rising groundwater in central London. Water and Sewerage Journal 4: 35-36.

Lewis, M.A., Cheney, C.S. \& Ó Dochartaigh. B.E. 2006. The national assessment of permeability indicies. British Geological Survey CommercialReport CR/06/160.

Macdonald, D.M.J., Hall, R., Carden, D., Dixon, A., Cheetham, M., Cornick, S. \& Clegg, M. 2007. Investigating the interdependencies between surface and groundwater in the oxford area to help predict the timing and location of groundwater flooding and to optimise flood mitigation measures. Proceedings of $42^{\text {nd }}$ Defra Flood and Coastal Management Conference.

MacDonald, A.M., Hughes, A.G., Vounaki, T., Graham, M.T., Lilly, A., Mansour, M. \& Stephens, C.A. 2008. Groundwater and the Forres (River Findhorn \& Pilmuir) flood alleviation schemes. British Geological Survey Commissioned Report $C R / 08 / 023$.

Marsh, T.J. \& Hanniford, J. 2008. The summer 2007 floods in England \& Wales - a hydrological appraisal. Centre for Ecology \& Hydrology Report.

Morris, S.E., Cobby, D. \& Parkes, A. 2007. Towards groundwater flood risk mapping. Quarterly Journal of Engineering Geology and Hydrogeology 40: 203-211.

Najib, K., Jourde, H. \& Pistre, S. 2008. A methodology for extreme groundwater surge predetermination in carbonate aquifers: groundwater flood frequency analysis. Journal of Hydrology 352: 1-15.

Newell, A.J. 2007. Morphology and Quaternary geology of the Thames floodplain around Oxford. British Geological Survey Open Report, OR/08/030.

Pitt, M. 2007. Learning lessons from the 2007 floods: An independent review by Sir Michael Pitt - Interim Report.

Price, M., Downing, R.A. \& Edmunds, W.M. 1993. The Chalk as an aquifer. In Downing Price and Jones, The Chalk of North-West Europe, Oxford Science Publications.

Price, M., Low, R.G. \& McCann, C. 2000. Mechanisms of water storage and flow in the unsaturated zone of the Chalk aquifer. Journal of Hydrology 233: 54-71.

Smith, D.B., Wearn, P.L., Richards, H,J, \& Rowe, P.C. 1970. Water movement in the unsaturated zone of high and low permeability strata using natural tritium. Isotope Hydrology 73-87. Int. Atomic Energy Agency, Vienna.

\section{ACKNOWLEDGEMENTS}

Maps with elements of Ordnance Survey topographic material are reproduced with the permission of Ordnance Survey on behalf of The Controller of Her Majesty's Stationery Office, (c) Crown Copyright. Unauthorised reproduction infringes Crown Copyright and may lead to prosecutionor civil proceedings. Licence Number: 100017897/2008. 